\title{
Cytotoxic Effects of Glycyrrhiza glabra L., Morus nigra L. and Urtica urens L. Extract against the Human Hepatocarcinoma HepG2 and Mouse L20B \\ Cell Lines \\ التأثيرات السمية لمستخلصات نباتات عرق السوس والتوت الأسود والمكيك ضد خط الخلايا الكبدية HepG2 و خط خلايا الفأر L20B
}

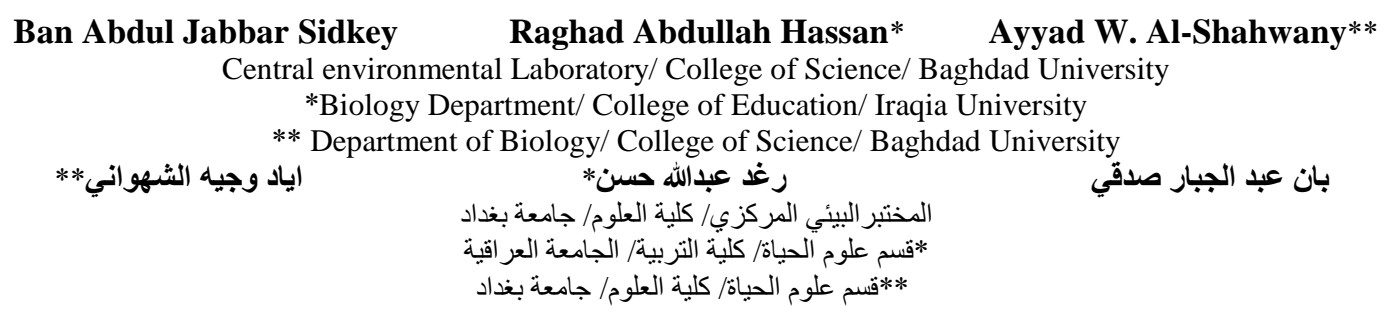

\section{E-mail: bansidkey@yahoo.com}

\begin{abstract}
The present study aimed to study the cytotoxic effects of three Iraqi traditional medical plants extracts using tissue culture teqnique on the human hepatocarcinoma HepG2 and mouse cell $\mathrm{L}_{20} \mathrm{~B}$ cell lines. Glycyrrhiza glabra L. root, Morus nigra L. and Urtica urens L. leaves were extracted using $99 \%$ ethanol solvent. Seven crude concentrations were prepared by serial dilution, with concentrations of 3.9, 7.81, $15.62,31.25,62.5,125$ and $250 \mathrm{mg} / \mathrm{ml}$, respectively. These were added to the microtiter plate containing $1 \times 10^{5}$ cells/well and $200 \mu \mathrm{l}$ of the medium. The seven concentrations were used in triplicate to investigate their cytotoxic and anti-proliferative effects. The analysis of chemical composition of these plant extracts were determined by fast liquid chromatography (FLC). The extract of Urtica urens L showed the highest potent cytotoxicity in the HepG2 and L20B cell lines, while both G. glabra L. and Morus nigra $L$. crude extracts showed the lowest cytotoxicity. All concentrations of crude extracts showed different cytotoxic activity in vitro.
\end{abstract}

Keywords: plant extracts, cytotoxic activity, HepG2, L20B.

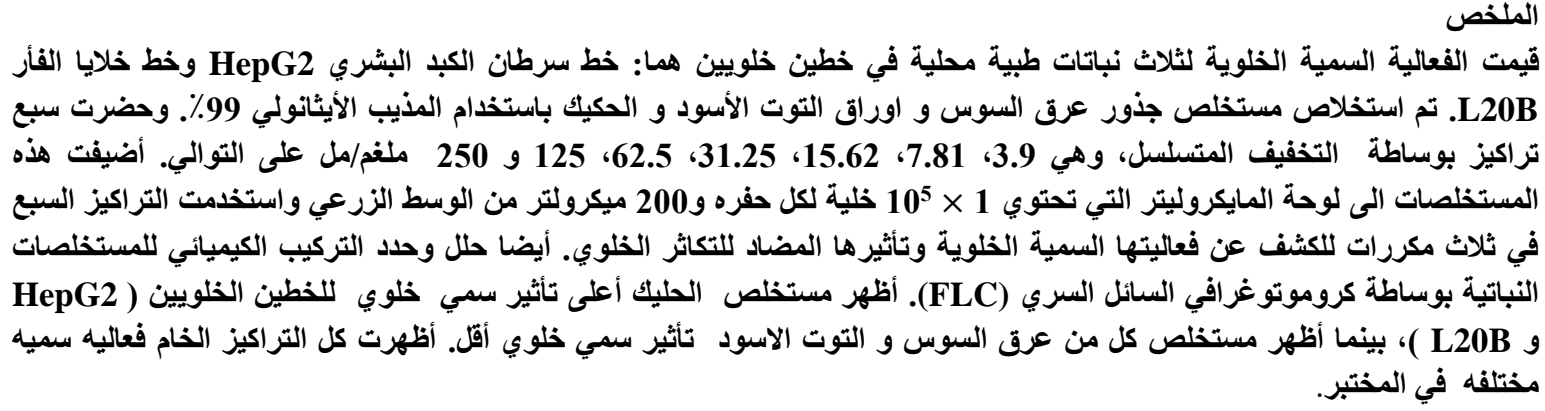

الكلمات الدالة: المستخلصات النباتية، تأثير سمي، خط الخلايا الكبدية و خط خلايا الفأر

\section{Introduction}

Cancer chemoprevention is the use of natural, artificial or biologic compounds to reverse, suppress or avoid the development of invasive cancer. Phytochemicals are attractive increasingly significant sources of chemo preventive agents, chiefly as they can reveal their useful potential at all stages of tumor configuration $[1,2]$. Among plant secondary metabolites phenols are of persistent interest as many epidemiological studies have shown a reduced risk of incidence of several cancers in individuals with the diet rich in fruits and vegetables $[3,4]$. In the pharmaceutical industry, improving the early detection of drug-induced hepatotoxicity is essential as it is one of the most important reasons for attrition of candidate drugs during the later stages of drug development [5].

The disease-prevention properties of fruits and vegetables are attributed to the biological activities of the dietary fiber, vitamins, minerals and phytochemicals in the plants, however many studies suggest the 
protective effects of fruits and vegetables against chronic diseases are due in large part to the phytochemical content of the plants [6,7].

In the traditional system of medicine, the roots and rhizomes of G. glabra have been in clinical use for centuries. Studies have shown that the extract of it has a growth inhibitory effect on breast cancer [8]. Methanol extract G. glabra roots have shown good antioxidant activity [9]. Glycyrrhizin acid found in $G$. glabra L. (liquorice) is a strong modulator of nontoxic oxidative mutagens and a potent scavenger of free radicals [10]. Also, Morus nigra fruits are source of secondary metabolites like flavonoids and anthocyanin which considered as an excellent antioxidant [11]. Beside, Leaves extracts of $U$. urens contain appreciable levels of polyphenols that have antioxidant action and radical scavengers $[12,13]$. The $U$. urens extract had a therapeutic action in different studies; preserving liver cirrhosis and fibrosis protect them against oxidative stress [14] and have anti-carcinogenic effects [15,16]. The aim of this study was to evaluated the cytotoxic effects of Glycyrrhiza glabra L., Morus nigra L., and Urtica urens L. extracts against HepG2 and $\mathrm{L}_{20} \mathrm{~B}$ cell lines in vitro.

\section{Materials and Methods}

\section{Plant materials}

Plant materials were collected from various parts of Baghdad -Iraq. Authentication of plant materials was carried out at the herbarium of the Department of Biology, College of Sciences/ Baghdad University/Iraq. The plant materials were rinsed thoroughly with tap water to remove extraneous contaminants and cut into small pieces, oven-dried at $50^{\circ} \mathrm{C}$ until stability of dry weight was observed, and then grounded into powder with an electric-grinder to prepare it for extraction [17].

\section{Preparation of crude extracts}

\section{Extraction was carried out by different steps}

1- Macerating (100 g) of plant materials in $500 \mathrm{ml}$ of $99 \%$ ethanol in $\left(25-30^{\circ} \mathrm{C}\right)$ for 7 days in stoppered flasks.

2- Filtration the extracted solvent and separated through Whatman No. 1 filter paper.

3- Evaporation the extracts under reduced pressure using rotary evaporation.

4- Weighed the crude extracts powder and stored at $4^{\circ} \mathrm{C}$ until used [18].

5- Dissolved the crude extracts powder in Dimethylsulphoxide (DMSO) in order to prepare different concentrations for use in cytotoxic assay [19].

\section{Cytotoxic assay experiment}

\section{Preparation of stock solution}

1- To prepare $400 \mathrm{mg}$ extract $/ 1 \mathrm{ml}$ medium stock solution mixing $400 \mu \mathrm{l}$ of crude extract with $10 \mu \mathrm{l}$ of DMSO, with the volume being completed up to $1 \mathrm{ml}$ using a serum free medium [20, 21].

2- Serial dilution prepared, with concentrations of 3.9, 7.81, 15.62, 31.25, 62.5, 125 and $250 \mathrm{mg} / \mathrm{ml}$, respectively and added in triplicate to the microtiter plate containing $1 \times 10^{5}$ ells/well and $200 \mu \mathrm{l}$ of the medium.

\section{Culture of cell lines}

HepG2 hepatocarcinoma and $\mathrm{L}_{20} \mathrm{~B}$ (a mouse cell line that expresses the genes for human cellular receptor for polio viruses) Cells were cultured in DMEM medium supplemented with $10 \%$ foetal bovine serum, Lglutamine. Cells were grown as a monolayer at $37^{\circ} \mathrm{C}$ with $5 \% \mathrm{CO}_{2}$. The experiments were performed when cells were in the logarithmic phase of growth [22]. Cell line was incubated with different concentrations of each plant extract. The nine concentrations were used in triplicate to investigate their cytotoxic and antiproliferative effects. A complete medium was used as negative control [22,23]. This experiment done at the Biotechnology Research Center / Al Nahrain University.

\section{Neutral red assay}

After incubating the cells with the extracts for 48 hours, the wells are washed with PBS and a freshly prepared neutral red solution ( $0.01 \mathrm{~g}$ of the dye is dissolved in $100 \mathrm{ml}$ of PBS, and used immediately). $(100 \mu 1 /$ well) is added and incubated for 2 hrs. Finally, wells were washed again with PBS to remove excessive dye. An elution buffer $(100 \mu \mathrm{l} /$ well) is added and the absorbance was measured using an ELISA reader at a wavelength of $492 \mathrm{~nm}$. The percentage of inhibition rate (IR) is calculated according to the formula: $(\% \mathrm{IR})=$ [absorption at $490 \mathrm{~nm}$ for control- absorption at $490 \mathrm{~nm}$ for volatile oil

$$
\text { absorption at } 490 \mathrm{~nm} \text { for control] x } 100
$$


Analysis of chemical composition of the plant extracts by FLC

The analysis of the chemical composition was made by fast liquid chromatography (FLC). FLC consists from a mobile phase which is polar and consists of a mixture of solvents such as water and acetonitrile, while the stationary phase comprises of a column which is usually stainless steel and packed with silica particles, a

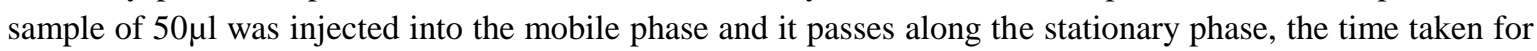
a sample to pass through the system is recorded as its retention time RT that is one of the characteristic used to identify the compound, all the compound were separated and identified using FLC with separation conditions C-18, $3 \mu \mathrm{m}$ particle size, $50 \times 4.6 \mathrm{~mm}$ internal diameter of the column, detection U.V. set at 280 $\mathrm{nm}$, flow rate $1.4 \mathrm{ml} / \mathrm{min}$. and $30 \mathrm{C}^{\circ}$. Mobile phase was $(0.1 \%$ acetic acid and acetonitrile with linear gradient from $0-100 \%$ B in $10 \mathrm{~min}$ ). Phenolic compounds and, deionized water: methanol 40:60 V/V or alkaloids and $0.1 \%$ acetic acid in deionized water: acetonitrile $(20-80 \mathrm{~V} / \mathrm{V})$. The area under a peak is used for calculating the concentration of a sample as the following formula was used:

\section{Conc. of sample $\left(\mu \mathrm{g} . \mathrm{ml}^{-1}\right)=$ Area of the sample $\times$ Standard conc.$\times$ Dilution factor Area of the standard}

Analysis of the chemical composition was made by injecting $20 \mu 1$ of the extract of each sample in FLC for identification. The conditions of separation were listed in Table (1). The peaks were detected by UV detector. The analysis was carried out in the laboratories of Ministry of Science and Technology [26].

Table (1): Conditions of Fast Liquid Chromatographic used for analysis of phenolic compounds of the plants extracts.

\begin{tabular}{|c|c|}
\hline Parameter & Characteristic \\
\hline Type of Column & C-18 \\
\hline Column dimensions & $3 \mu \mathrm{m}$ particle size $(50 \times 4.6 \mathrm{~mm}$ ID $)$ \\
\hline Flow Rate & $1.4 \mathrm{ml} / \mathrm{min}$ \\
\hline Detector & UV spectrophotometer at $280 \mathrm{~nm}$ \\
\hline Volume injection sample & $20 \mu \mathrm{l}$ \\
\hline Mobile phase & $\begin{array}{c}\text { Solvent A : 0.1\% phosphoric acid in deionized water } \\
\text {.Solvent B 20:80 V/V , 0.1\% phosphoric acid in deionized } \\
\text { water : acetonitrile HPLC grade, linear gradients } 0 \% \text { B- } \\
100 \% \text { B. }\end{array}$ \\
\hline Temperature & $30^{\circ} \mathrm{C}$ \\
\hline
\end{tabular}

\section{Statistical Analysis} $30^{\circ} \mathrm{C}$

The results obtained were statistically analysed using SAS software (version 17; SAS Inc., Chicago, IL, USA) [27].

\section{Results and Discussion}

\section{The Cytotoxicity assay}

The ethanol extracts showed clear inhibitory action against the proliferation of the hepatocellular carcinoma cell line after $48 \mathrm{hrs}$. The ethanol extract resulted in a dose dependent decrease in cell viability. The sensitivity of the ethanol extract was more in higher dosage especially with G. glabra and U. urens extract Table (2). Treatment with the G. aglabra extract $(250 \mu \mathrm{g} / \mathrm{mL})$ decreased the cell viability of hepatocellular carcinoma HepG2 with value of $92.1 \%$ IR after $48 \mathrm{hrs}$. and further decreased to $88.00 \%$ IR for $U$. urens extract after $48 \mathrm{~h}$ compared to the control cells, respectively Table (2).

Table (2): The cytotoxic effect expressed as the inhibition rate percentage (\%IR) for different concentrations of the extracts after 48 hours exposure of the HepG2 cell line.

\begin{tabular}{ccccc}
\hline Concentratio & \multicolumn{3}{c}{ Inhibition rate percentage (\%IR) } & \multicolumn{3}{c}{ HepG2 cell line } \\
\cline { 2 - 5 } ns mg/ml & $\begin{array}{c}\text { Glycyrrhiza glabra } \\
\text { extract }\end{array}$ & $\begin{array}{c}\text { Morus nigra } \\
\text { extract }\end{array}$ & $\begin{array}{c}\text { Urtica urens } \\
\text { extract }\end{array}$ & Mean \\
Control & 0.00 & 0.00 & 0.00 & 0.00 \\
31.25 & 14.0 & 10.5 & 37.0 & 20.3 \\
62.5 & 37.5 & 56.5 & 50.0 & 48 \\
125 & 52.0 & 21.5 & 70.00 & 47.3 \\
250 & 92.0 & 41.5 & $\mathbf{8 8 . 0 0}$ & 73.3 \\
Mean & 39.1 & 26 & 49 & \\
LSD value & $4.31^{*}$ & $3.51^{*}$ & $4.90^{*}$ & \\
\hline
\end{tabular}

Also, all these extracts have same cytotoxic effects against L20B cells line. Treatment with the U. urens and G. aglabra extracts $(250 \mu \mathrm{g} / \mathrm{mL})$ decreased the cell viability of hepatocellular carcinoma and $\mathrm{L}_{20} \mathrm{~B}$ cells line value of 93.00 and $92.00 \%$ IR after $48 \mathrm{hrs}$. respectively, further decreased to $41.8 \%$ IR after $48 \mathrm{hrs}$ and for $M$. 
nigra extract compared to the control cells Table (3). These results may be attributed to their contents of polyphenols, flavonoids, anthocyanin's, ellagitannins, and vitamin C. It is the phytochemicals that are responsible for many of the biological activities of theirs crude extracts, including antioxidant, reduce inflammatory and anticancer properties $[11,12,13,15]$.

Table (3): The cytotoxic effect expressed as the inhibition rate percentage (\% IR)for different concentrations of extracts after 48 hours exposure of the $L_{20} B$ cell lines.

\begin{tabular}{ccccc}
\hline Concentrations & \multicolumn{4}{c}{ Inhibition rate percentage (\% IR) L20B cell line } \\
\cline { 2 - 5 } Mg/ml & $\begin{array}{c}\text { Glycyrhiza } \\
\text { extract }\end{array}$ & $\begin{array}{c}\text { Morus nigra } \\
\text { extract }\end{array}$ & $\begin{array}{c}\text { Urtica urens } \\
\text { extract }\end{array}$ & Mean \\
Control & 0.00 & 0.00 & 0.00 & 0.00 \\
31.25 & 44.5 & 30.5 & 67.0 & 47.3 \\
62.5 & 57.5 & 39.5 & 70.5 & 55.6 \\
125 & 72.0 & 41.5 & $\mathbf{8 1 . 0 0}$ & 64.8 \\
250 & 92.0 & 41.8 & 93.00 & 75.3 \\
Mean & 53.2 & 30.6 & 62.2 & \\
LSD value & $5.01 *$ & $3.59^{*}$ & $5.96^{*}$ & \\
\hline
\end{tabular}

\section{Chemical identification of plant crude extracts using FLC}

FLC chromatograms in Table (4) and Figures (1- 3) were used as a references for quality control in future experiments. Commonly found in these plants, the phenolic compounds were used as markers in our experiments. Pure compounds, namely gallic acid, chlorogenic acid, catechin, epicatechin, caffeic acid, vanillic acid, vanillin, coumaric acid, ferulic acid and quercetin, were used as marker compounds. Results of FLC of the U. urens, G. glabra and M. nigra extracts referred to present of phenols. The action activity of phenol extracts depends upon their active components. However, the biological effect is often due to a synergic action between the compounds [28]. Thus, the extracted phenols in this study were analyzed in a screening for the most active compounds (Chlorogenic acid, Caffeic acid and Gallic acid) that most topics and studies referred that antimicrobial activity due to them. According to the results of the profile FLC, this showed that the total concentrations of phenolic compounds were the highest in U. urens than of those in other tested extracts. The M. nigra extracts showed the lowest inhibitory action against hepatocarcinoma HepG2 and $\mathrm{L}_{20} \mathrm{~B}$ cell lines which could primarily due to its values of the phenolic compounds which were the lowest than in the other extracts in this study.

When phenolic compounds represent one of the most important allelochemicals as [29] referred that phenols are very active substances. Nakai et al. [30] reported that plant extracts from Cyperus alternifolius and Cana generalis, had active inhibitory effects against cyanobacteria due to release allelochemicals and they screened for these allelochemicals. they found 9 phenolic compounds [resorcinol, 3-hydroxy benzoic acid, 4-hydroxy benzoic acid, (4-hydroxyphenyl) acetic acid, vanillic acid, protocatechic acid, p-coumaric acid, gallic acid, and ferulic acid], in which anti-cyanobacterial activity were involved, vanillic acid, protocatechuic acid, pcoumaric acid and gallic acid. Rice [31] reported eight phenolic compounds produced by plants inhibited the growth of Anabaene sp. and Lyngbya sp. which were chlorogenic acid, coumaric acid, gallic acid, iso chlorogenic acid, scopoletin, $\alpha$-naphthol, tannic acid and hydroxybezaldehyde, thus, chlorogenic acid, coumaric acid, gallic acid were recorded in most extracts in this study and they may played the inhibitory role of these extracts against hepatocarcinoma HepG2 and $\mathrm{L}_{20} \mathrm{~B}$ cell lines.

Table (4): Types and concentrations of phenols in plant extracts

\begin{tabular}{|c|c|c|c|c|c|c|c|c|}
\hline 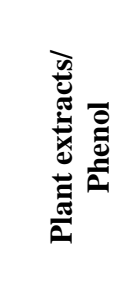 & 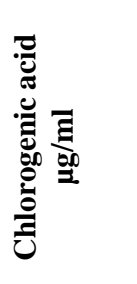 & لَّ & 氖 & 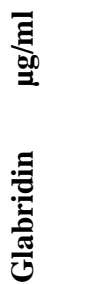 & 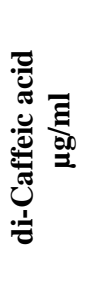 & 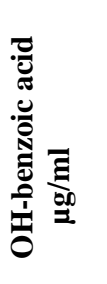 & 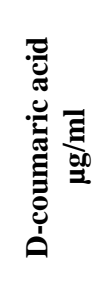 & 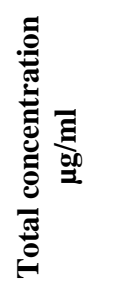 \\
\hline U. urens & 116.802 & 82.871 & 155.49 & ------- & ------ & 43.00 & 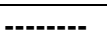 & 398.163 \\
\hline G.glabra & ---------. & 111.93 & ------- & 218.83 & ------- & ----- & 66.85 & 397.61 \\
\hline M. nigra & 125.22 & 23.93 & ------- & ------ & 91.03 & ------. & 41.96 & 282.14 \\
\hline
\end{tabular}




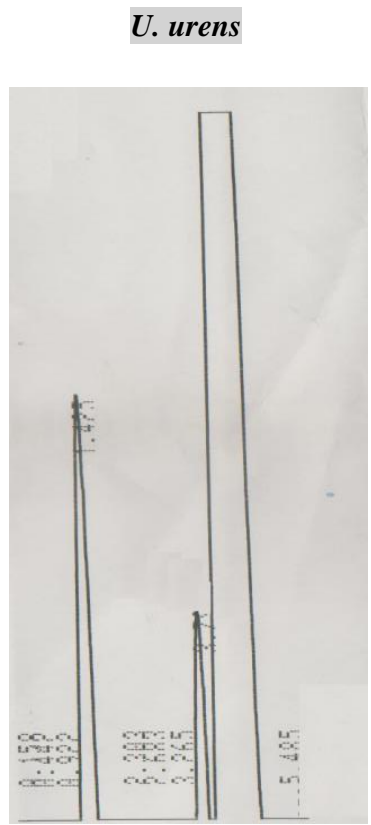

Standard

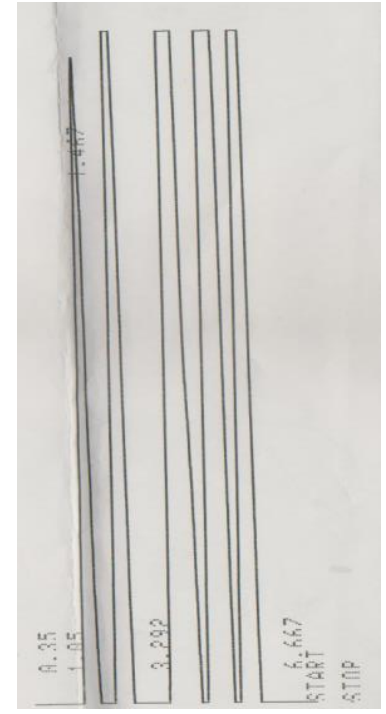

Fig. (1): FLC profile of phenols in $U$. urens.
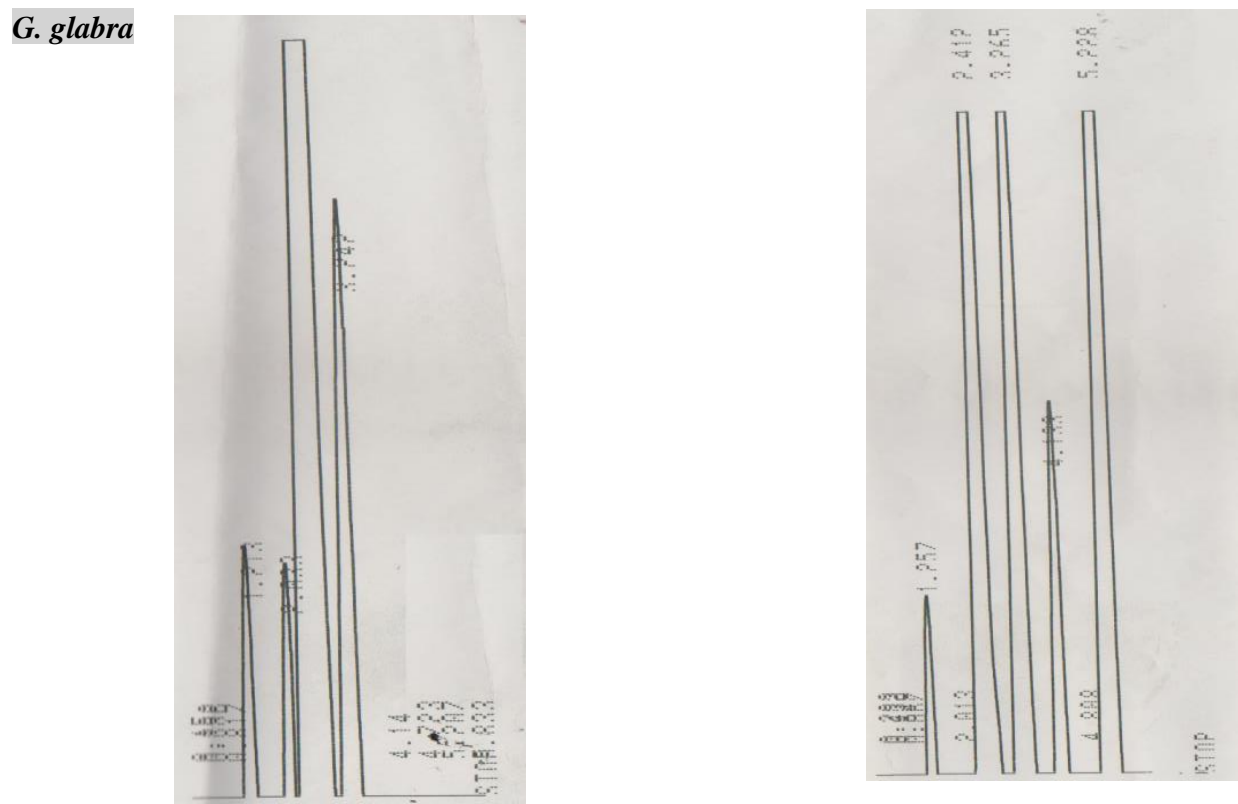

Standard curve

Fig. (2): FLC profile of phenols in G. glabra. 

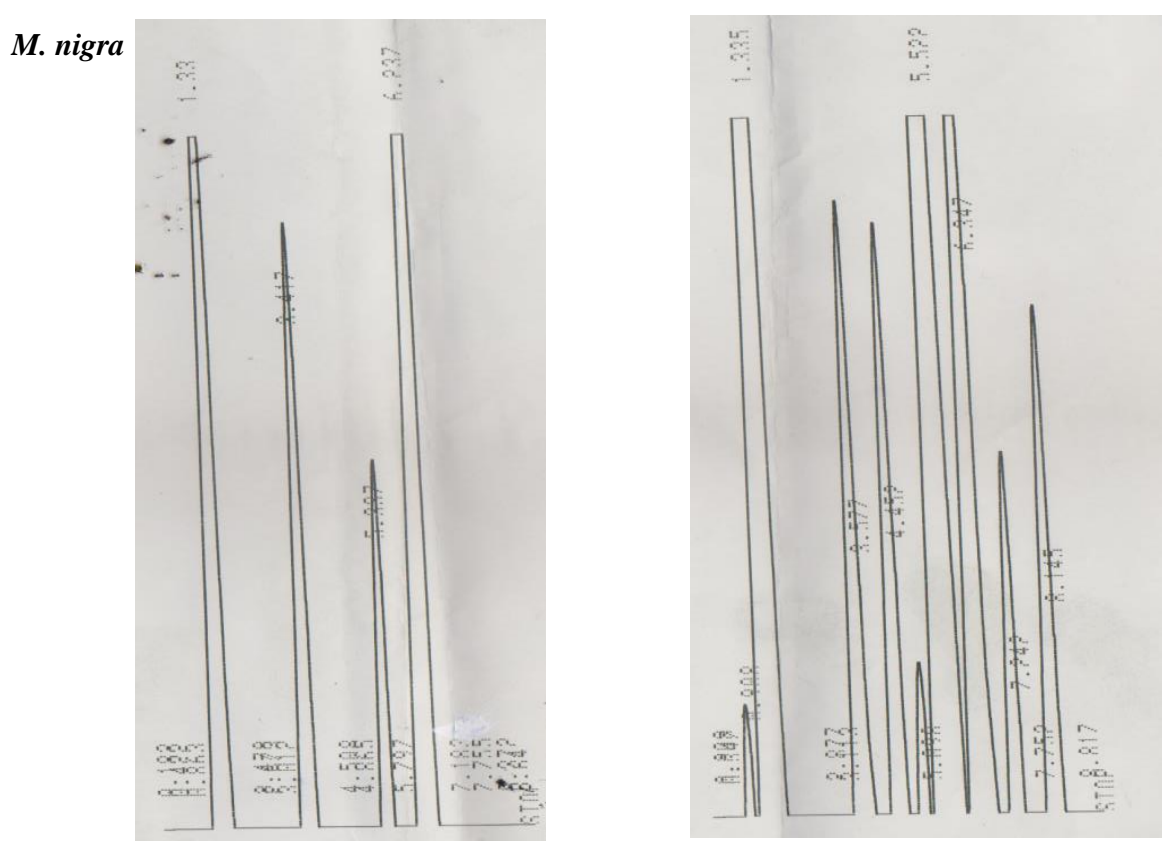

Standard curve

Fig. (3): FLC profile of phenols in M. nigra

\section{Conclusions}

The crude extract of the Glycyrrhiza glabra L., Morus nigra L. and Urtica urens L. have the ability to inhibit the growth activity and reduce the proliferation of cell lines used in this study.

\section{References}

1. Verschaeve, L. and Van Staden, J. (2008). Mutagenic and anti-mutagenic properties of extracts from South African traditional medicinal plants. Journal of Ethnopharmacol. 119:575-587.

2. Kumar, S., Rao, M. and Balasubramanian, M. (2011). Anticarcinogenic effects of Indigofera aspalathoideson 20-Methylcholanthrene induced fibro sarcoma in rats. Research Journal of Medicinal plant. 5:745-755.

3. Eldeen, I., Elgrashi, E. and Van Stden, J. (2005). Antibacterial, anti-inflammatory, anti-cholinesterase and mutagenic effects of extracts obtained from trees used in South Africa traditional medicine. Journal of Enthnopharmacol. 102:457-464.

4. Dohi, S., Teriyaki, M. and Makino, M. (2005). Acetylcholinesterase inhibitory activity and chemical composition of commercial essential oils. Journal of Agriculture and food Chemistry. 57:4313-4318.

5. Asl, M.N. and Hosseinzadeh, H. (2008). Review of pharmacological effects of Glycyrrhiza sp. and its bioactive compounds . Phytotherapy Research. 22:709-724.

6. Yang, J., Hsia, T., Kuo H., Chao, P., Chou, C., Wei Y. and Chung, J. (2006). Inhibition of Lung Cancer Cell Growth by Quercetin Gulcuroni des via G2/M Arrest and Induction of Apoptosis. Drug Metabolism and Disposition. 34: 296 -304.

7. Feng, R., Ni, H., Wang, S., Tourkova, I., Shurin, M., Harada, H. and Yin, X. (2007). Cyanidin-3-rutinoside, a Natural Polyphenol Antioxidant, Selectively Kills Leukemic Cells by Induction of Oxidative Stress. Journal of Biological Chemistry. 282(18): 13468 - 13476.

8. Tamir, S., Eizenberg, M., Somigen, D., Stern, N., Shelach, R., Kaye, A. and Vaya, J. (2000). Estrogenic and antiproliferative properties of glabridin from liqorice in human breast cancer cells. Cancer Research. 60(20):5704-5709.

9. Giatr Chopra, P.K.P., Saraf, B.D., Inam, F. and Deo,S.S. (2013). Antimicrobial and antioxidant activities of methanol extract roots of Glycyrrhiza glabra and HPLC analysis. International Journal of Pharmacy and Pharmaceutical Siences. 5(2):157-160.

10. Kaur, P., Sharma, N., Singh, B., Kumar, S. and Kaur, S. (2012). Modulation of genontoxicity of oxidative mutagens by glycyrrhizic acid from Glycyrrhiza glabra L. Pharmacognosy research. 4(4):189-195.

11. Runner, O.M., Majinda, R.T. and Mothanka, D. (2011). Antioxidant and antibacterial constituents from Morus nigra. African Journal of Pharmacy and Pharmacology. 5 (6):751-754.

12. Issa, N.K. and Abd-Aljabar, R.S. (2013). Evaluation of Antioxidant Properties of Morus nigra L. Fruit Extracts. Jordan Journal of Biological Sciences. 6(4):258-265.

13. Qadir, M.I., Ali, M. and Ibrahim, Z. (2014). Anticancer activity of Morus nigra leaves extracts. Bangladesh Journal of Pharmacology. 9(4):496-497. 
14. Agabeyli, R.A. (2012). Antimutagenic activities extracts from leaves of Morus alba, Morus nigra and their mixtures. International Journal of Biology. 4(2):166-172.

15. Jimoh, F., Adedapo, A., Aliero, A. and Afolayan, A. (2010). Polyphenolic and biological activities of leaves extracts of Argemone subfusiformis (Papaveraceae) and Urtica urens (Urticaceae). International Journal of Tropical Biology. 58(4):1517-1531.

16. Rahman, M.A., Rana, M.S., Zaman, M.M., Uddin, S.A. and Akter, R. (2010). Anitoxidative, antibacterial and cytotoxic activity of the methanol extract of Urtica granulate. Journal of Scientific Research. 2(1):169177.

17. Alattin, S.E.N., Barbaros, S.A.H.I.N., Hizian, H.A., Merve, B., Hatic, S. and Ali, S. (2007). Prevention of carbon tetrachloride-induced hepatotoxicity by Urtica urens .Journal of Applied Biologogical Sciences. $1(3): 29-32$.

18. Harput, U.S., Saracoglu, I. and Ogihara, Y. (2005). Stimulation of lymphocyte proliferation and inhibition of nitric oxide production by aqueous Urtica dioca extract. Phototherapy Research. 19(4):346-348.

19. Zheng, Z., Cheng, K., Zhu, Q., Wang, X., Lin, Z. and Wang, M. (2010). Tyrosinase inhibitory constituents from the roots of Morus nigra: Structure-activity relationship. Journal of Agricultural and Food Chemistry. 58:5368-5373.

20. Khalid, N., Fawad, S.A. and Ahmed, I. (2011). Antimicrobial activity, phytochemical profile and trace minerals of black mulberry (Morus nigra L.) fresh juice. Pakistan Journal of Botany. 43:91-96.

21. Cavanagh, H., Hipwell, M., Wilkinson, J. (2003). Antibacterial Activity of Berry Fruits Used for Culinary Purposes. Journal of Medicinal Food. 6(1): $57-61$.

22. Camille, S., Forbes, Yanjun, Z. and Muralledharan, G. (2010). Anthocyanin content, antioxidant, antiinflammatory and anticancer properties of blackberry and raspberry fruits. Journal of Food Composition and Analysis. 23: 554-560.

23. Dheeb, B. I., Mohammad, F. I., Hadi, Y. A. and Abdulhameed, B. A. (2013). Cytotoxic Effect of Aflatoxin B1, gliotoxin, Fumonisin B1, and Zearalenone Mycotoxins on HepG2 Cell Line in vitro. International Journal of Advanced Research. 1(8): 355-363.

24. Freshney R. I. (2000). Culture of animal cells: A manual for basic techniquell 4th Ed.Wiley-Liss, A John wiley and Sons, Inc. Publication, New York. pp 45-60.

25. Freshney, I.R. (2001). Culture of animal cells: A manual for basic technique. Wiley-Liss publication, New York. pp 122-124.

26. Perucka, M. (2005). Antioxidant activity of main phynolic compounds isolated from hot peppers Capsicum annum L. Journal of Agricultural and Food Chemistry. 53(5):1750-1756.

27. SAS users. (2004). "Guide personal compute"r (ver.7) inst. Inc. Cary. Nc. USA.

28. Sonboli, A, Babakhani, B. and Mehrabian, A.R. (2006). Antimicrobial activity of six constituents of essential oil from Salvia. Z Naturforsch C. 61(3-4):160-164.

29. Nakai, j., Ohkura, M., Imoto, k. (2001). A high signal-to-noise Ca (2+) probe composed of a single green fluorescent protein. National Biotechnology. 19:137-14.

30. Nakai, Y., Nakai, M., Hayashi, H. (2008). Thio-modification of yeast cytosolic tRNA requires a ubiquitinrelated system that resembles bacterial sulfur transfer systems. Journal of Biological Chemistry. 283: 2746927476.

31. Rice, E.L. (1984). Allelopathy. 2nd Edition, Academic Press, New York, pp 422. 